\title{
IDIOSYNCRATIC RISK AND FIRM CHARACTERISTICS ON ISLAMIC STOCKS OF FOUR ASEAN COUNTRIES 2005-2017
}

\author{
Putri Utami \\ Universitas Indonesia \\ Muhammad Budi Prasetyo* \\ Universitas Indonesia
}

\begin{abstract}
This research investigates idiosyncratic volatility in the Islamic stock of four ASEAN countries, namely Indonesia, Malaysia, Singapore, and Thailand for 2005-2017. The volatility will be analyzed based on the idiosyncratic volatility levels of each country. Furthermore, firm characteristics will be used to determine their relationship to the idiosyncratic volatility movement. This study used the Fama-French Three-Factor model for obtaining the realized value of idiosyncratic volatility. Furthermore, a panel data regression is used to estimate the relationship between firm characteristics and idiosyncratic volatility. The results of this research suggest that mean value of idiosyncratic risk in the Islamic stock of ASEAN countries is below the non-Islamic stock in the United States but above non-Islamic stock in Hong Kong. Meanwhile, after the global financial crisis of 2008, the relationship between return and idiosyncratic risk of Islamic stock changed in all four countries. Panel data regression of firm characteristics shows that firm size is significantly negative in all four countries, while share turnover is insignificant to idiosyncratic volatility.
\end{abstract}

Keywords: idiosyncratic risk, Fama-French Three-Factor model, firm characteristics, Islamic stock

Received: 29 January 2019

Accepted: 11 June 2020

\section{INTRODUCTION}

In the last two decades, studies related to risk-return trade-off have been discussed, especially after the appearance of studies conducted by Ang, Hodrick, Xing, and Zhang (2006). Their findings show that in the US stock market, stocks with high idiosyncratic volatility have low average returns. Ang, Hodrick, Xing, and Zhang (2009) continued their studies on the international stock market and found consistent results. However, studies conducted by Fu (2009) showed different results. He found a positive relationship between idiosyncratic volatility and stock returns. On the international stock market, there are several studies whose results differ from Ang et al., (2009). Some of these findings conclude that there is either a positive relationship between idiosyncratic volatility and stock returns (Brown \& Ferreira, 2016; Chua, Goh, \& Zhang, 2010; Hur, Pettengill,

\footnotetext{
- Corresponding author: Faculty Economics and Business Universitas Indonesia, Address: Fakultas Ekonomi dan Bisnis, Jalan Prof. Dr. Sudjono D Pusponegoro, Kampus Universitas Indonesia, Depok, West Java, Indonesia; Phone: +627272425; Email: m.budi.prasetyo@ui.ac.id.
} 
\& Singh, 2014) or the relationship between the two is not yet clear (Bali \& Cakici, 2008; Wang, Lin, Kang, \& Fung, 2016). These contradictory results indicate that studies related to idiosyncratic volatility, and returns are sensitive to market characteristics and the method used to measure idiosyncratic volatility.

Markowitz (1959) and Sharpe (1964) stated that idiosyncratic risk should be eliminated by diversifying assets through portfolio formation. If there is a large enough number of assets in the portfolio, then the idiosyncratic characteristics will go away, so that investors only focus on the systematic risk of the portfolio. However, according to Malagon, Moreno, and Rodríguez (2015), many investors do not diversify optimally on their portfolio. Goetzmann and Kumar (2008) found that individual investors tend to have under-diversified portfolios: These are mostly young, low income, and inexperienced investors. Vozlyublennaia (2013) found that idiosyncratic risk accounts for almost $90 \%$ of total risk in the stock market. Hence, idiosyncratic risk should be included in an asset pricing model.

In recent years, Islamic finance has shown high growth, increasing from \$200 billion in 2003 to $\$ 1.8$ trillion in 2013. Although growth has slowed in recent years, Islamic finance remains a concern of market participants worldwide. Azmi, Ng, Dewandaru, and Nagayev (2019) showed that the Islamic stock market has a share of about a third of the total assets in Islamic finance. Several previous studies have argued that Islamic stock has much in common with Socially Responsible Investment (SRI). Ashraf and Mohammad, (2014) stated that Islamic stocks are low risk because they have better financial conditions than conventional stocks. While Hoepner, Rammal, and Rezec (2011) showed that Islamic stocks have the characteristics of small-cap and growth stock with low book-to-market ratio, previous studies showed that small-cap and growth stock are usually high risk.

This study aims to measure idiosyncratic volatility in Islamic stocks and the characteristics of the firms that influence it. Vozlyublennaia (2013) showed several firm characteristics, such as bookto-market ratio, leverage, size, institutional ownership, earning power, and turnover, all of which explain the idiosyncratic volatility. The characteristics of the firm can be used as a relative indicator of idiosyncratic risk between stocks, making investment decisions easier. For investors who are interested in Islamic stocks, information about firm characteristics and idiosyncratic volatility can help them make the right decisions.

Most previous studies on this topic have measured idiosyncratic volatility and the factors that influenced it in developed countries such as the United States. For example, the study conducted by Vozlyublennaia (2013) used the US stock market as a research sample. To our knowledge, studies related to idiosyncratic volatility and the factors that influence it are still limited in developing countries and the Islamic stock market. We use the stock markets of four countries in ASEAN as a research sample. The four countries are Indonesia, Malaysia, Singapore, and Thailand. Yang and Hamori (2014) stated that ASEAN stock markets, despite being in stilldeveloping countries, have continued to grow and develop in recent years. Chien, $\mathrm{Lee}, \mathrm{Hu}$, and $\mathrm{Hu}$ (2015) also mentioned that ASEAN's position in the world economy was becoming increasingly important, especially for international fund managers. The four countries also have Islamic stock markets that are relatively advanced compared to other ASEAN countries. The MSCI AC ASEAN Islamic Index fund allocates its funds to the four ASEAN countries. A total 
of $29.27 \%$ was allocated to the Thai stock market, $24.54 \%$ to the Malaysian stock market, and $21.51 \%$ to the Singapore stock market, and the rest was allocated to the Indonesian stock market. This study has some interesting results. First, we find that the mean value of idiosyncratic risk in Islamic stock of these ASEAN countries is below the non-Islamic stock in the United States but above the non-Islamic stock in Hong Kong. This shows that the Islamic stock markets in the four ASEAN countries are an attractive to investors because of the competitive level of risk. Second, the estimated results using panel data regression show that some firm characteristics have a significant impact on the idiosyncratic volatility of Islamic stock. However, the share turnover variable cannot explain idiosyncratic volatility.

This research paper is organized as follows. Section 1 introduces an overview of Islamic stock and idiosyncratic risk. Section 2 presents a relevant literature review of this research. Section 3 gives a brief explanation of the research methodology. Section 4 presents the results and a discussion. Section 5 concludes this research.

\section{LITERATURE REVIEW}

The fundamental difference between Islamic and non-Islamic stock lies in the screening process for obtaining the Sharia-compliant stocks. The concept of capital participation and profit-sharing does not conflict with Sharia principles. Sharia principles include prohibition of business activities that contain elements of interest (riba), gambling (maysir), and uncertainty (gharar). Derigs and Marzban (2008) stated that the Sharia screening process is conducted with a two-tier screening process. The first phase of business screening is conducted to select the activities of firms that adhere to Sharia principles. Firms that pass the business screening process then proceed to the second stage of financial screening with four ratios: the ratio of liquidity, interest ratio, debt ratio, and ratio of interest income. Business activities that do not comply with Shariah include alcohol products, cigarettes, pork products, nonpermissible entertainment, weapons, and conventional financial services (Ho, 2015).

The estimation of risk and return is prominent in all kinds of investments. That estimation, in general, is known as an asset pricing model. The sophisticated asset pricing method was invented by Sharpe (1964), who termed it the Capital Asset Pricing Model (CAPM). CAPM is an asset pricing calculation in which the expected return from the portfolio is linked to risk factors in the market. The CAPM model predicts the relationship between risk and the equilibrium of expected returns in an asset. CAPM assumes that idiosyncratic risk can be eliminated by diversification. Therefore, investors only get compensation for systematic risk. The risk of a portfolio is not only influenced by the systematic risk indicated by the beta coefficient but also the risk premium, which is the yield obtained from the portfolio after deducting the risk-free investment.

Roll (1977) had criticisms of the CAPM model and stated that the real value of the market portfolio cannot be observed, thus the CAPM calculation cannot be verified. Furthermore, Fama and French (1992) stated that firm characteristics such as size and book-to-market ratio are better at predicting expected returns than beta on CAPM. Fama and French (1992) conducted research by including factor size, book-to-market equity ratio, earnings per price $(\mathrm{E} / \mathrm{P})$, leverage, and $\beta$ market to find a correlation with the average stock return in the cross-section. When $\beta$ market is used alone or simultaneously with other variables, the variable only gives limited information about the average 
stock return. Meanwhile, market capitalization (ME) and book-to-market equity ratio (BE/ME) can explain average return on stock better than other variables.

\subsection{Idiosyncratic Risk}

Idiosyncratic risk is inherent risk tied to the internal characteristics of a firm and is not affected by market conditions $(\mathrm{Fu}, 2009)$. This risk reflects the specific information within the firm that is substantially volatile over time, such as demand and supply, competitors' business movements, and periodic financial statements. Idiosyncratic risk is also referred to as "unsystematic risk," "firm-specific risk," "unique risk," or "residual risk." Idiosyncratic risk can reflect changes in the stock price when there is an event that affects the company itself, such as a labor strike (Bansal \& Clelland, 2004). The anomaly of idiosyncratic risk and return only emerged after the research conducted by Ang et al., (2006), which will be referred to as AHXZ in this study. AHXZ finds a negative relationship between idiosyncratic risk and expected return, which is often called a "puzzle" because financial literature often states either a positive relationship or no relationship at all between idiosyncratic risk and expected return (Malagon et al., 2015).

Some research only focuses on idiosyncratic risk and return relationships. However, an investor needs to develop his or her portfolio based on factors that may affect idiosyncratic risk. The characteristics of firms that explain future idiosyncratic volatility will render the risk in the portfolio to be controllable and predictable (Vozlyublennaia, 2013).

\subsection{Islamic Stock and Idiosyncratic Risk}

Jawadi, Jawadi, and Louhichi (2014), argued that Islamic instruments can be an alternative investment strategy due to the process of ethical screening, or Sharia screening. Ameer, (2015), working from the assumption that Islamic investors' portfolios are underdiversified, finds stocks that are not Sharia compliant have higher idiosyncratic risk than when still included in the Sharia index. The framework of Islamic finance lies in ethically oriented business, socially responsible investment, and a well-regulated financial system (Jawadi et al., 2014). Hence, the Sharia screening process has the same characteristics as a socially responsible investment (SRI) (Galema, Plantinga, \& Scholtens, 2008). Kurtz (1997) argued that social screening criteria on SRI lead to uncompensated risk or idiosyncratic risk even though the portfolio has been considerably diversified. Uncompensated risk arises due to predetermined social screening criteria, which is nonrandom, while the diversification process usually has random elements to it. Thus, according to Kurtz (1997) the diversification process still raises uncompensated risk (idiosyncratic risk) due to a mismatch between the social screening process and diversification.

\section{METHODOLOGY}

This research uses secondary data such as risk-free rate, market value, book-to-market ratio, and stock prices obtained from Datastream Thomson Reuters. The type of data used is time-series data in the form of daily data from June 2005 until December 2017. This research also uses quarterly data from market value, book-to-market ratio, total debt to total asset ratio, share turnover, and earnings per share of stocks listed on the stock exchange of each country for panel data regression. The list of Islamic stocks used in this research includes those stocks that have passed the Sharia 
screening process. Islamic stock in Indonesia is obtained from the Daftar Efek Syariah (DES) issued by Otoritas Jasa Keuangan (OJK) per January 2018. Meanwhile, Islamic stock in Malaysia is issued by the Securities Commission (SC) as per December 2017. Nevertheless, for the Islamic stock of Singapore and Thailand, the screening process is executed by the author with criteria used by Morgan Stanley Capital International (MSCI) Islamic Index Series. Hence, by including stocks that have successfully passed the Sharia screening process, the number of Islamic stocks for each country is 350 in Indonesia, 573 in Malaysia, 131 in Singapore, and 312 in Thailand.

\subsection{Research Model}

In this study, we use the Fama-French Three-Factor model to measure the idiosyncratic volatility of each stock. We have also considered using the latest risk factor model from the Fama-French Four- and Five-Factor model, but this model is not feasible because of the number of stocks available to create momentum, investment, and profitability is limited. In addition, most of the previous studies (Ang et al., 2006; Fu, 2009; Nartea, Wu, \& Liu, 2013; Vozlyublennaia, 2013) used a three-factor model to estimate idiosyncratic volatility. The Fama-French Three-Factor model is formulated as follows:

$$
R_{i \tau}-r_{\tau}=\alpha_{i t}+\beta_{i t}\left(R_{i \tau}-r_{t}\right)+s_{i t} S M B_{\tau}+h_{i t} H M L_{\tau}+\varepsilon_{i \tau}
$$

$R_{i \tau}$ is stock return, $r_{\tau}$ is risk-free rate, $\alpha_{i t}$ is intercept, $\beta_{i t}$ is the parameter of market risk factor, $R_{m t}$ is market return, $s_{i t}$ is the parameter of size factor, $h_{i t}$ is the parameter of value factor, $S M B_{\tau}$ is size factor (small minus large), $H M L_{\tau}$ is value factor (high minus low), and $\varepsilon_{i, t}$ is the residual from the three-factor model. $t$ is subscript for the month, and subscript $\tau$ is subscript for the day. Equation (1) above $\mathrm{s}$ is estimated every month for each stock using daily data. We also use data filtering as per Fama and French (1993), where firms with a negative book-to-market ratio are removed from the portfolio. After the SMB and HML values are obtained, then the regression is processed with the time-series Fama-French Three-Factor model to get the residual value for each stock. The $\varepsilon_{i \tau}$ component in equation (1) is important for estimating the idiosyncratic volatility for each stock. Idiosyncratic volatility is standard deviation from $\varepsilon_{i \tau}$ in equation (1). To transform it to monthly, we multiply the standard deviation of the residual by the square root of the number of trading days in a month. In accordance with the approach used by $\mathrm{Fu}$ (2009), only stocks that have more than 15 trading days are included in the sample. To control outliers in the data, we Winsorize each tail of the data distribution by a particular threshold.

The determinants used are firm characteristics, where the research model uses the empirical model of Vozlyublennaia (2013). To know the predictive power of firm characteristics, the variables are the lag one period for each characteristic. The regression model is stated in the following formulation:

$$
\begin{aligned}
I V O L_{(i t)}= & \omega_{0 i}+\omega_{1 i} I V O L_{i t-1}+\omega_{2 i} B M_{i t-1}+\omega_{3 i} S I Z E_{i t-1} \\
& +\omega_{4 i} L E V_{i t-1}+\omega_{5 i} E P S_{i t-1}+\omega_{6 i} T_{U R N} N_{i t-1}+e_{i \tau}
\end{aligned}
$$

Equation (2) is estimated using the panel data model, and each country is estimated separately. We use the Hausman test to decide whether to use a fixed or random effect as an estimation method. Also, the data used for estimating equation (2) are data for the period 2005-2017 with quarterly 
frequency. Although idiosyncratic volatility has a monthly frequency, the independent variable in equation (2) is a variable derived from financial statements that are only available every quarter. Therefore, we use quarterly data to estimate equation (2).

Table 1 below shows the definition of each variable used in equation (2).

Table 1: Variable Definition

\begin{tabular}{|c|c|}
\hline Variable & Definition \\
\hline IVOL & $\begin{array}{l}\text { Idiosyncratic volatility, } \\
\text { estimated with the Fama-French } \\
\text { Three-Factor model. }\end{array}$ \\
\hline $\mathrm{BM}$ & Book-to-market ratio \\
\hline SIZE & $\begin{array}{l}\text { The logarithm of firm's total } \\
\text { assets }\end{array}$ \\
\hline LEV & $\begin{array}{l}\text { Debt ratio (total debt divided by } \\
\text { total assets) }\end{array}$ \\
\hline EPS & Earnings per share \\
\hline TURN & $\begin{array}{l}\text { Share turnover of stock in the } \\
\text { stock market }\end{array}$ \\
\hline
\end{tabular}

\section{RESULTS AND DISCUSSION}

\subsection{Time-series properties of idiosyncratic volatility}

The results will be compared with the findings of $\mathrm{Fu}$ (2009), in which the idiosyncratic volatility estimation method is used. However, since the period of Fu's (2009) study is in 1963-2006 and does not cover the global economic crisis of 2007-2009, the research will be further compared with Nartea et al., (2013) research on non-Islamic stock in Hong Kong between 1992 and 2011.

Table 1 showed that Indonesia has the highest mean idiosyncratic volatility value compared to other ASEAN countries, which is 0.148. It indicates that Islamic stocks in Indonesia are riskier than in the three other countries. Compared to the findings of $\mathrm{Fu}(2009)$, the fourth mean value of idiosyncratic volatility in ASEAN countries is still below the non-Islamic stock in the United States, which is 0.169. However, compared to the findings of Nartea et al., (2013), which is 0.013, the mean value of idiosyncratic volatility in ASEAN countries is much higher than that of nonIslamic stocks in Hong Kong. The standard deviation of Indonesian Islamic stock also shows the highest value compared with the other three countries, which is $10 \%$. These results indicate that Islamic stocks in Indonesia have the highest idiosyncratic risk among the three other countries.

Compared with the findings of $\mathrm{Fu}$ (2009), which is 9.94\%, the standard deviation value of idiosyncratic volatility of Indonesian Islamic stock is slightly above the non-Islamic stock. The value of the coefficient of variance (CV) of Indonesia also shows the highest value that is equal to 0.67 , which indicates that the standard deviation of idiosyncratic volatility is $67 \%$ times its mean value. Sharia stocks in Thailand are suitable for risk-averse investors who want stocks with low volatility levels. The CV value of these four countries is higher than that of Fu's (2009) $55 \%$ and Nartea et al., (2013) findings of $30 \%$. 
Table 2: Descriptive Statistics of Idiosyncratic Volatility

\begin{tabular}{clcccc}
\hline \hline & \multicolumn{1}{c}{ Country } & $\boldsymbol{N}$ & Mean & St. Dev & $\boldsymbol{C V}$ \\
\hline \multirow{3}{*}{$I V O L$} & Indonesia & 350 & 0,148 & 0,1 & 0,67 \\
& Malaysia & 573 & 0,136 & 0,05 & 0,5 \\
& Singapore & 131 & 0,111 & 0,07 & 0,52 \\
& Thailand & 312 & 0,094 & 0,04 & 0,46 \\
\hline \multirow{2}{*}{$\operatorname{Ln}\left(\frac{I V O L_{t}}{I V O L_{t-1}}\right)$} & Indonesia & 350 & $-0,038$ & 0,76 & 17,4 \\
& Malaysia & 573 & 0 & 0,6 & $-100,59$ \\
& Singapore & 131 & $-0,008$ & 0,6 & 274,24 \\
& Thailand & 312 & $-0,021$ & 0,56 & $-50,55$ \\
\hline \hline
\end{tabular}

Note: This table summarizes the descriptive statistics of time-series from individual Islamic stocks. Stocks are traded in four ASEAN countries from June 2005 to December 2017. The idiosyncratic volatility (IVOL) is estimated every month as a residual value of the Fama-French Three-Factor model time-series regression.

To identify the time-series property of idiosyncratic volatility, we used the approach used by $\mathrm{Fu}$ (2009), which uses the standard test in univariate time series, namely the identification of autocorrelation and unit root test. Both tests are conducted to prove whether idiosyncratic volatility has a random walk process, as stated by Ang et al., (2006). If idiosyncratic volatility follows a random walk process, then the first difference of idiosyncratic volatility is white noise, and there is no autocorrelation in any lags. The results of the autocorrelation in each lag are summarized in Table 3, and the unit root test results are shown in Table 4. It can be seen that the autocorrelation value of Indonesia shows a pattern where data is significant, not equal to zero, and the coefficient of each lag decreases slowly. The findings in Indonesia have the same pattern with the findings of $\mathrm{Fu}$ (2009), in which the autocorrelation coefficient value of each lag is not equal to zero and decreases slowly.

Meanwhile, idiosyncratic volatility in Islamic stocks in Malaysia and Thailand does not have a time trend where the autocorrelation value of each lag shows a different pattern. For Islamic stock in Singapore, there is a trend in the five-lag period. This suggests that idiosyncratic volatility in Islamic stock in Singapore is correlated up to the fifth lag period. Besides, the unit root test results using the Dickey-Fuller test showed that idiosyncratic volatility in three countries (Indonesia, Malaysia, and Thailand) showed that they did not follow the random walk process and did not contain a unit root. Thus, the time-series property of idiosyncratic volatility from three countries in ASEAN is consistent with the findings of Fu (2009). Idiosyncratic volatility does not follow a random walk process and has an autocorrelation with decay to zero autocorrelation. Although the unit root test results show that Singapore's idiosyncratic volatility contains unit roots, Singapore's idiosyncratic volatility autocorrelation pattern in Table 3 shows an autocorrelation pattern that tends to decrease. 
Table 3: Idiosyncratic Volatility Time-Series Properties

\begin{tabular}{|c|c|c|c|c|c|c|c|c|}
\hline \multicolumn{9}{|c|}{ Autocorrelation (Lag) } \\
\hline IVOL & 1 & 2 & 3 & 4 & 5 & 11 & 12 & 13 \\
\hline Indonesia & $0,497^{* * *}$ & $0,383^{* * *}$ & $0,286^{* *}$ & $0,266^{* *}$ & $0,275^{* *}$ & $0,264^{* *}$ & $0,284^{* *}$ & $0,301^{* *}$ \\
\hline Malaysia & 0,010 & $0,227^{* *}$ & $0,112^{*}$ & 0,051 & $0,213^{*}$ & $-0,074^{*}$ & $0,215^{* *}$ & $-0,074^{*}$ \\
\hline Singapore & $0,342^{* *}$ & $0,424^{* * *}$ & $0,382^{* * *}$ & $0,269^{* *}$ & $0,476^{* * *}$ & 0,062 & $0,290^{* *}$ & 0,012 \\
\hline Thailand & 0,006 & $0,229^{* *}$ & $0,168^{*}$ & $-0,005$ & $0,279^{* *}$ & $-0,138^{*}$ & $0,157^{*}$ & $-0,241^{* *}$ \\
\hline
\end{tabular}

Note: This table summarizes the autocorrelation series from individual Islamic stocks. Stocks are traded in four ASEAN countries from June 2005 to December 2017. The idiosyncratic volatility (IVOL) is estimated every month as residual value of the Fama-French Three-Factor model time-series regression. ${ }^{* * *}$ significant at level $1 \%,{ }^{* *}$ significant at level $5 \%$, *significant level $10 \%$.

Table 4: Unit Root Test for Idiosyncratic Volatility

\begin{tabular}{lcc}
\hline \hline Country & \multicolumn{2}{c}{ t-stat } \\
\hline Indonesia & -5.321 & $* * *$ \\
Malaysia & -6.678 & $* * *$ \\
Singapore & -2.236 & \\
Thailand & -6.642 & $* * *$ \\
\hline \hline
\end{tabular}

\subsection{Idiosyncratic volatility analysis}

The observation of the idiosyncratic volatility of Islamic stocks during the 2008 global economic crisis indicates a pattern. Based on Figure 1, it can be seen that all idiosyncratic volatility of Islamic stock from the four ASEAN countries shows a similar pattern during the global economic crisis. Figure 1 shows idiosyncratic volatility reached its highest value in the last 13 years during the period of the 2008 global economic crisis. Furthermore, the idiosyncratic volatility value will be classified based on research conducted by Nartea et al., (2013), which divides the portfolio into three parts. The group is classified based on the degree of idiosyncratic volatility, which is High Idiosyncratic Volatility (HIV), Medium Idiosyncratic Volatility (MIV), and Low Idiosyncratic Volatility (LIV). Idiosyncratic volatility is also divided into three periods, based on the 2008 global financial crisis event. The three periods are: full period, precrisis period, and postcrisis period. The idiosyncratic volatility classification will be analyzed with some factors such as return, book to market, and firm size. The results of this classification is presented in Table 5. 
Figure 1: Idiosyncratic Volatility Trends

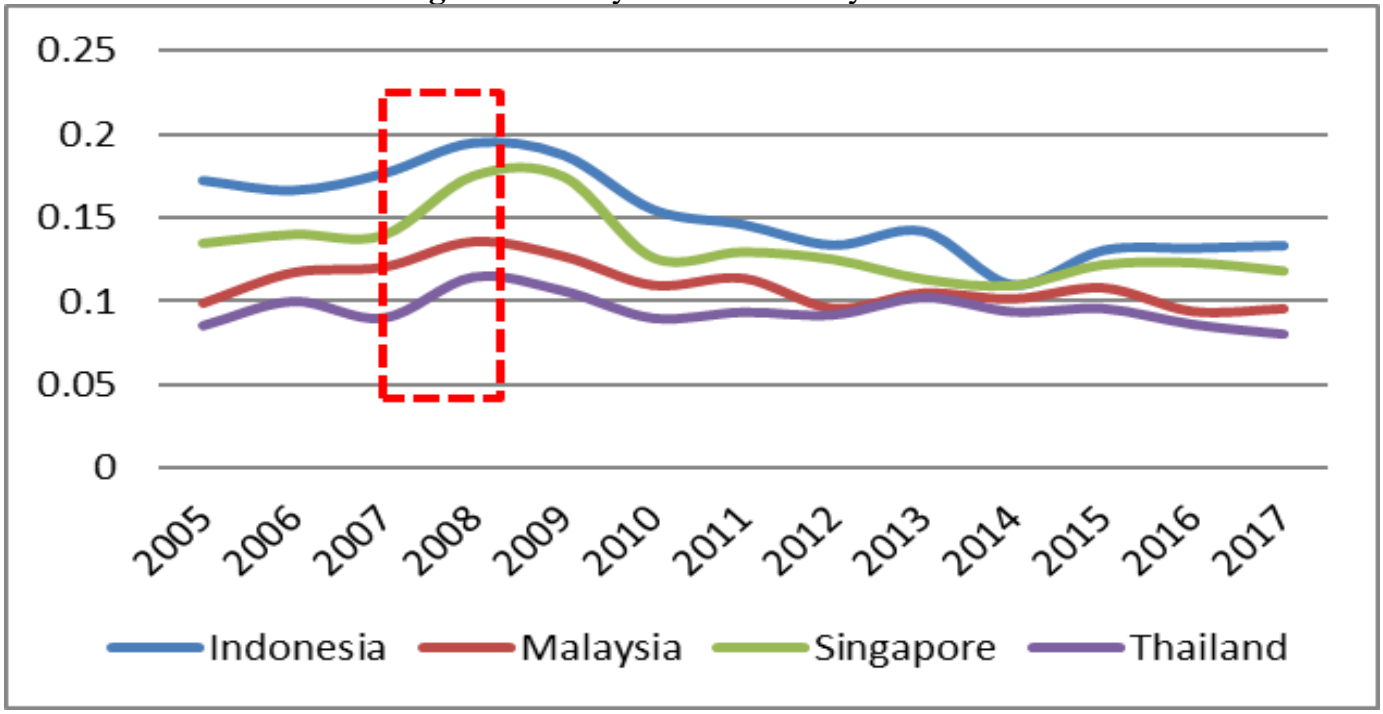

Based on the results of the full period in Table 5, Indonesia's Islamic stock, which is small size and low book to market value (growth stock) have high idiosyncratic risk (HIV). This is followed by a low average return, which is 0,0004 . Thus, it was found that Islamic stocks from small-cap firms in Indonesia tend to be riskier. In Malaysia, Islamic large-cap stocks with high book-to-market value have higher idiosyncratic risk (HIV) but low average return. Investors who expect a high average return can invest in stocks with small market cap value (small cap) and also have a low book-to-market ratio (growth stock). Islamic stocks in Singapore with small size and high book-tomarket value have higher idiosyncratic risk (HIV) but high average return. The general condition of Islamic stock in Singapore reflects the high-risk, high return assumption. Risk-averse investors in Singapore can choose Islamic stock from firms with large market cap value (big-cap) and high market price (overvalued). Meanwhile, Thailand's Islamic stocks are in some ways similar to Singapore's full period result, which is that small size and high book-to-market value (value stock) have higher idiosyncratic risk and average return. Thus, investors who expect to get a high average return value will obtain Islamic stock with high idiosyncratic risk levels. Risk-averse investors in Thailand can avoid stocks from small companies with high book-to-market ratios. It indicates that risk-averse investors in Thailand can choose Islamic stock from large market cap value (big-cap) and high market price (overvalued) firms.

Table 5 also shows that the relationship between Islamic stock returns and idiosyncratic volatility changes in all four countries in the period after the 2008 global financial crisis. It indicates the financial crisis significantly impacted the risk and return relationship of Islamic stocks in the four ASEAN nations. 
Table 5: Idiosyncratic Volatility on Islamic Stock Portfolio

\begin{tabular}{|c|c|c|c|c|c|c|}
\hline \multirow{2}{*}{ Model Factors } & \multicolumn{3}{|c|}{ Indonesia } & \multicolumn{3}{|c|}{ Malaysia } \\
\hline & LIV & MIV & HIV & LIV & MIV & HIV \\
\hline & \multicolumn{6}{|c|}{ Full Period (July 2005-December 2017) } \\
\hline $\operatorname{Return}\left(\mathrm{x} 10^{2}\right)$ & 0,0044 & 0,012 & 0,0004 & 0,0067 & 0,006 & 0,0064 \\
\hline $\mathrm{Bm}$ & 1,0669 & 1,1235 & 1,0328 & 1,471 & 1,5358 & 1,5077 \\
\hline \multirow[t]{2}{*}{ Size (Ln) } & 15,7097 & 15,7745 & 15,4682 & 6,8519 & 6,7621 & 6,9684 \\
\hline & \multicolumn{6}{|c|}{ Precrisis Period (July 2005-July 2007) } \\
\hline $\operatorname{Return}\left(\mathrm{x} 10^{2}\right)$ & 0,0423 & $-0,0115$ & $-0,0294$ & $-0,0366$ & $-0,0374$ & $-0,0523$ \\
\hline $\mathrm{Bm}$ & 1,0689 & 1,2964 & 1,1999 & 1,3814 & 1,4439 & 1,3469 \\
\hline Size (Ln) & 14,9148 & 15,4807 & 14,6029 & 5,923 & 6,1416 & 6,7128 \\
\hline \multicolumn{7}{|c|}{ Postcrisis Period (May 2009-December 2017) } \\
\hline $\operatorname{Return}\left(\mathrm{x} 10^{2}\right)$ & 0,0008 & 0,0215 & 0,013 & 0,0096 & 0,0082 & 0,015 \\
\hline $\mathrm{Bm}$ & 1,0556 & 1,041 & 0,9898 & 1,4534 & 1,5122 & 1,5084 \\
\hline \multirow[t]{3}{*}{ Size (Ln) } & 16,1267 & 15,8986 & 15,6857 & 7,2397 & 6,987 & 7,1363 \\
\hline & \multicolumn{3}{|c|}{ Singapore } & \multicolumn{3}{|c|}{ Thailand } \\
\hline & LIV & MIV & HIV & LIV & MIV & HIV \\
\hline & \multicolumn{6}{|c|}{ Full Period (July 2005-December 2017) } \\
\hline $\operatorname{Return}\left(\mathrm{x} 10^{2}\right)$ & $-0,0025$ & 0,0008 & 0,0012 & 0,0052 & 0,0044 & 0,0098 \\
\hline $\mathrm{Bm}$ & 0,9397 & 1,1537 & 1,3952 & 0,8153 & 0,8629 & 0,864 \\
\hline Size (Ln) & 6,7821 & 5,9645 & 4,881 & 9,7473 & 9,2374 & 9,2498 \\
\hline \multicolumn{7}{|c|}{ Precrisis Period (July 2005-July 2007) } \\
\hline Return(x10²) & $-0,0316$ & $-0,0374$ & $-0,0488$ & $-0,0055$ & $-0,0463$ & $-0,0295$ \\
\hline $\mathrm{Bm}$ & 0,7873 & 0,857 & 0,8646 & 0,8964 & 0,916 & 1,028 \\
\hline Size (Ln) & 6,5559 & 6,1241 & 4,7543 & 9,9103 & 8,9277 & 8,8868 \\
\hline \multicolumn{7}{|c|}{ Postcrisis Period (May 2009-December 2017) } \\
\hline $\operatorname{Return}\left(\mathrm{x} 10^{2}\right)$ & 0,0127 & 0,005 & 0,0136 & 0,007 & 0,0122 & 0,0194 \\
\hline $\mathrm{Bm}$ & 0,9626 & 1,169 & 1,4842 & 0,7466 & 0,7564 & 0,7329 \\
\hline Size $(\mathrm{Ln})$ & 6,8988 & 5,9874 & 4,8129 & 9,7649 & 9,3949 & 9,3843 \\
\hline
\end{tabular}

Note: This table classifies the degree of idiosyncratic volatility (IVOL) also with factors such as return, book- to-market ratio (Bm) and firm size (Size). The degree of IVOL is divided into three categories that have high idiosyncratic volatility $(H I V)$, medium idiosyncratic volatility (MIV), and low idiosyncratic volatility (LIV. For comprehensive comparison, the period is also divided into full period, precrisis period, and postcrisis period.

\subsection{Panel Data Regression Results}

Firm characteristics that affect the dynamic of idiosyncratic volatility will be regressed with the panel data method (equation [2]). We first performed the Hausman test to select the panel data estimation method to be used. The Hausman test results are shown in Table 6 where all results in all countries consistently chose the fixed-effect model.

Based on Table 6, share turnover has no significant effect on idiosyncratic volatility on Islamic stock in four ASEAN countries, and it is evident that liquidity does not affect the movement of idiosyncratic risk in the Islamic stock of these countries. Vozlyublennaia (2013) also found that only about 15 to $20 \%$ of stock turnover has a significant relationship with idiosyncratic volatility. Meanwhile, firm size is significant in the four ASEAN countries, even though the size of the firms negatively affects the idiosyncratic risk. This indicates that smaller firms tend to have higher risk levels in the four ASEAN countries. 
Leverage is only significant in Malaysia and Singapore. Rasiah, Cheong, and Doner (2014) found that Singapore is applying a leverage strategy to increase technological investment in that country, while Malaysia also increased technological investment despite being hampered by political and ethnic issues. Earnings per share as a proxy of profitability is also significant in Malaysia and Singapore. Meanwhile, the book-to-market ratio is only significant in Indonesia and Malaysia. The book-to- market ratio has a different influence in each country. In Indonesia, Islamic growth stock (low book-to-market ratio) tends to be riskier. On the contrary, Islamic value stock (high book-tomarket ratio) in Malaysia has higher idiosyncratic risk. There are two major viewpoints on those findings. Vozlyublennaia (2013) stated that value stock has a low risk. Meanwhile, Brandt, Brav, Graham, and Kumar (2010) stated that growth stocks are also low risk because the stock has a lower market price, thus it can be preferred by speculators who make the value of the stock riskier.

Table 6. Panel Data Regression Result

\begin{tabular}{lllll}
\hline \hline & Indonesia & Malaysia & Singapore & Thailand \\
\hline $\mathrm{C}$ & 0,390 & 0,077 & 0,257 & 0,109 \\
& {$[5,63]^{* * *}$} & {$[10,23]^{* * *}$} & {$[6,34]^{* * *}$} & {$[4,84]^{* * *}$} \\
$\left.\mathrm{IVOL}_{\mathrm{t}-1}\right)$ & 0,1557 & 0,206 & 0,215 & 0,157 \\
& {$[7,18]^{* * *}$} & {$[5,40]^{* * *}$} & {$[4,52]^{* * * *}$} & {$[5,06]^{* * *}$} \\
$\mathrm{BM}_{\mathrm{t}-1}$ & $-0,009$ & 0,008 & $-0,003$ & $-0,001$ \\
& {$[-2,69]^{* * *}$} & {$[3,10]^{* * *}$} & {$[-0,84]$} & {$[-0,34]$} \\
$\mathrm{LEV}_{\mathrm{t}-1}$ & 0,000 & 0,000 & 0,003 & 0,000 \\
& {$[0,06]$} & {$[1,66]^{*}$} & {$[2,09]^{* *}$} & {$[1,08]$} \\
$\mathrm{SIZE}_{\mathrm{t}-1}$ & -0.018 & $-0,000$ & $-0,027$ & $-0,008$ \\
& {$[-3,70]^{* * *}$} & {$[-2,97]^{* * *}$} & {$[-3,58]^{* * *}$} & {$[-2,08]^{* *}$} \\
$\mathrm{TURN}_{\mathrm{t}-1}$ & 0,000 & 0,000 & $-0,002$ & 0,002 \\
& {$[0,28]$} & {$[0,18]$} & {$[-0,80]$} & {$[1,51]$} \\
EPS & $-0,002$ & $-0,021$ & 0,055 & $-0,000$ \\
& {$[-0,80]$} & {$[-2,40]^{* *}$} & {$[3,04]^{* * *}$} & {$[-0,47]$} \\
R2 & $25 \%$ & $42 \%$ & $53 \%$ & $28 \%$ \\
F-Statistik & 4,17 & 17,22 & 21,98 & 10,98 \\
Hausman test & Fixed Effect & Fixed Effect & Fixed Effect & Fixed Effect \\
\hline \hline
\end{tabular}

Note: This table summarizes panel data regression for the relationship between idiosyncratic volatility and firm characteristics. ${ }^{* * *}$ significant at level $1 \%,{ }^{* *}$ significant at level $5 \%$, *significant level $10 \%$.

\section{CONCLUSION}

This research aims to analyze idiosyncratic risk in Islamic stocks in four ASEAN countries: Indonesia, Malaysia, Singapore, and Thailand. Islamic stocks in Indonesia have higher levels of idiosyncratic risk, which indicates Indonesia's Islamic stocks are riskier than stocks in the other three countries in terms of unsystematic risk. Stock diversification is important for those investing in Islamic stock in Indonesia. However, in a broader sense, the Islamic stock's idiosyncratic volatility, out of the four ASEAN countries, is still below the level of non-Islamic stocks in the U.S. market (emerging market) as seen in Fu (2009). But this is higher than Nartea et al., (2013) finding on non-Islamic stock in Hong Kong.

Furthermore, in the relationship between firm characteristics and idiosyncratic risk, only firm size has a significant negative effect in all four countries. This finding is also consistent with 
Vozlyublennaia's (2013) finding in the US market that a negative relationship emphasizes that stocks from small firms tend to have higher idiosyncratic risk than big firms. Meanwhile, share turnover has no significant effect on idiosyncratic risk in Islamic stock in the four ASEAN countries. This indicates that liquidity does not affect the idiosyncratic risk of Islamic stocks in ASEAN countries.

\section{REFERENCES}

Ameer, R. (2015). Idiosyncratic Risk of Investing in Islamic Capital Market Equities. The Journal of Investing, 24(2), 79-89. doi: https://doi.org/10.3905/joi.2015.24.2.079

Ang, A., Hodrick, R. J., Xing, Y., \& Zhang, X. (2006). The Cross-Section of Volatility and Expected Returns The Cross-Section of Volatility and Expected. Journal of Finance, 61(1), 259-299. doi: https://doi.org/10.1111/j.1540-6261.2006.00836.x

Ang, A., Hodrick, R. J., Xing, Y., \& Zhang, X. (2009). High idiosyncratic volatility and low returns: International and further U.S. evidence. Journal of Financial Economics, 91(1), 123. doi: https://doi.org/10.1016/j.jfineco.2007.12.005

Ashraf, D., \& Mohammad, N. (2014). Matching perception with the reality-Performance of Islamic equity investments. Pacific Basin Finance Journal, 28, 175-189. doi: https://doi.org/10.1016/j.pacfin.2013.12.005

Azmi, W., Ng, A., Dewandaru, G., \& Nagayev, R. (2019). Doing well while doing good: The case of Islamic and sustainability equity investing. Borsa Istanbul Review, 19(3), 207-218. doi: https://doi.org/10.1016/j.bir.2019.02.002

Bali, T. G., \& Cakici, N. (2008). Idiosyncratic Volatility and the Cross Section of Expected Returns. Journal of Financial and Quantitative Analysis, 43(1), 29-58. doi: https://doi.org/10.1017/s002210900000274x

Bansal, P., \& Clelland, I. (2004). Talking trash: Legitimacy, impression management, and unsystematic risk in the context of the natural environment. Academy of Management Journal, 47(1), 93-103. doi: https://doi.org/10.2307/20159562

Brandt, M. W., Brav, A., Graham, J. R., \& Kumar, A. (2010). The idiosyncratic volatility puzzle: Time trend or speculative episodes. Review of Financial Studies, 23(2), 863-899. doi: https://doi.org/10.1093/rfs/hhp087

Brown, D. P., \& Ferreira, M. A. (2016). Idiosyncratic Volatility of Small Public Firms and Entrepreneurial Risk. Quarterly Journal of Finance, 6(1),1-59. doi: https://doi.org/10.1142/s2010139216500026

Chien, M. S., Lee, C. C., Hu, T. C., \& Hu, H. T. (2015). Dynamic Asian stock market convergence: Evidence from dynamic cointegration analysis among China and ASEAN-5. Economic Modelling, 51, 84-98. doi: https://doi.org/10.1016/j.econmod.2015.06.024

Chua, C. T., Goh, J., \& Zhang, Z. (2010). Expected volatility, unexpected volatility, and the crosssection of stock returns. Journal of Financial Research, 32(2), 103-123. doi: https://doi.org/10.1111/j.1475-6803.2010.01264.x

Derigs, U., \& Marzban, S. (2008). Review and analysis of current Shariah-compliant equity screening practices. International Journal of Islamic and Middle Eastern Finance and Management, 1(4), 285-303. doi: https://doi.org/10.1108/17538390810919600

Fama, E. F., \& French, K. R. (1992). The Cross-Section of Expected Stock Returns. Journal of Finance, 47(2), 427-465. doi: https://doi.org/10.2307/2329112

Fama, E. F., \& French, K. R. (1993). Common risk factors in the retunrs on stocks and bonds. 
Journal of Financial Economics, 33, 3-56.

$\mathrm{Fu}, \mathrm{F}$. (2009). Idiosyncratic risk and the cross-section of expected stock returns. Journal of Financial Economics, 91(1), 24-37. doi: https://doi.org/10.1016/j.jfineco.2008.02.003

Galema, R., Plantinga, A., \& Scholtens, B. (2008). The stocks at stake: Return and risk in socially responsible investment. Journal of Banking and Finance, 32(12), 2646-2654. doi: https://doi.org/10.1016/j.jbankfin.2008.06.002

Goetzmann, W. N., \& Kumar, A. (2008). Equity portfolio diversification. Review of Finance, 12(3), 433-463. doi: https://doi.org/10.1093/rof/rfn005

Ho, C. S. F. (2015). International comparison of Shari???ah compliance screening standards. International Journal of Islamic and Middle Eastern Finance and Management, 8(2), 222 245. doi: https://doi.org/10.1108/IMEFM-07-2014-0065

Hoepner, A. G. F., Rammal, H. G., \& Rezec, M. (2011). Islamic mutual funds' financial performance and international investment style: Evidence from 20 countries. European Journal of Finance. 17(9-10), 829-850. doi: https://doi.org/10.1080/1351847X.2010.538521

Hur, J., Pettengill, G., \& Singh, V. (2014). Market states and the risk-based explanation of the size premium. Journal of Empirical Finance, 28, 139-150.

Jawadi, F., Jawadi, N., \& Louhichi, W. (2014). Conventional and Islamic stock price performance : International Economics, 137(6211), 73-87. doi: https://doi.org/10.1016/j. inteco.2013.11.002

Kurtz, L. (1997). No Effect, or No Net Effect? Studies on Socially Responsible Investing. The Journal of Investing, 6(4), 37-49. doi: https://doi.org/10.3905/joi.1997.37

Malagon, J., Moreno, D., \& Rodríguez, R. (2015). The idiosyncratic volatility anomaly: Corporate investment or investor mispricing? Journal of Banking and Finance, 60, 224-238. doi: https://doi.org/10.1016/j.jbankfin.2015.08.014

Markowitz, H. M. (1959). Portfolio selection: Efficient diversification of investments (pp. 102115). New York: John Wiley \& Sons, Inc

Nartea, G. V., Wu, J., \& Liu, Z. (2013). Does idiosyncratic volatility matter in emerging markets? Evidence from China. Journal of International Financial Markets, Institutions and Money, 27(1), 137-160. doi: https://doi.org/10.1016/j.intfin.2013.09.002

Rasiah, R., Cheong, K. C., \& Doner, R. (2014). Southeast Asia and the Asian and Global Financial Crises. Journal of Contemporary Asia, 44(4), 572-580. doi:https://doi.org/10.1080/00472336.2014.933062

Roll, R. (1977). A critique of the asset pricing theory's tests Part I: On past and potential testability of the theory. Journal of Financial Economics, 4(2), 129-176. doi: https://doi.org/10.1016/0304-405X(77)90009-5

Sharpe, W. F. (1964). Capital Asset Prices: A Theory of Market Equilibrium under Conditions of Risk. The Journal of Finance, 19(3), 425-442. doi: https://doi.org/10.2307/2977928

Vozlyublennaia, N. (2013). Do firm characteristics matter for the dynamics of idiosyncratic risk? Journal of International Financial Markets, Institutions and Money, 27(1), 35-46.

Wang, L. H., Lin, C. H., Kang, J. H., \& Fung, H. G. (2016). Idiosyncratic volatility and excess Return: Evidence from the Greater China region. Finance Research Letters, 19, 126-129. doi: https://doi.org/10.1016/j.frl.2016.07.003

Yang, L., \& Hamori, S. (2014). Spillover effect of US monetary policy to ASEAN stock markets: Evidence from Indonesia, Singapore, and Thailand. Pacific Basin Finance Journal, 26, 145 155. doi: https://doi.org/10.1016/j.pacfin.2013.12.003 